REFLECTIONS:

NEUROLOGY AND THE

HUMANITIES

Section Editor

Anne W. McCammon,

MD, FAAN

\title{
Reflections for December
}

O’Neill F. D'Cruz, MD, MBA, FAAN

Address correspondence and reprint requests to Dr. O'Neill F. D’Cruz, Medical DirectorNeurology, UCB Pharma, 8010 Arco Corporate Drive, Suite 100, Raleigh, NC 27617 oneill_dcruz@yahoo.com

\section{GOING HOME}

"I'm waiting here till you let me know you can hear me." No response. The girl lay immobile on the clinic examination table, with closed eyes and an expressionless face.

The nurse aides from the rehabilitation center exchanged a skeptical glance. Had I not seen the 8 weeks of nursing record entries ("no response")? What did I expect to accomplish during a routine clinic follow-up visit? Out of the corner of my eye, I saw a head shake in disbelief and heard a stifled sigh. They had planned for a quick visit, and a van would be coming soon for the 2-hour return trip. Waiting for a response was not an efficient use of anyone's time. How could they know that I had waited for this visit for 8 years? Sharing Bella's story might help them understand my apparently irrational insistence. I held her hand while recounting the challenges that started when Bella was in kindergarten.

When I first saw Bella, she was a happy little girl with a propensity for seizures. The convulsions would occur without warning, leaving one side of her body weak. Bella seemed unaware of any weakness while playing with her many friends. She loved to talk to anyone who would listen, and proudly displayed her artwork during visits. Over the next few years, Bella's tendency for seizures became a habit. Even Bella could tell when she was "goin' to have one." Medicines which controlled seizures for several months initially worked for a few weeks at a time. After several drugs had failed to stop the seizures, Bella underwent a brain biopsy. The results confirmed my concerns: half her brain would need to be surgically removed to stop further seizures. Her mother would not consider such a drastic step. She asked about other treatment options.

There was a remote possibility-an infusion that would help Bella's immune system to fight seizures. It was not a cure, but had worked in similar cases when surgery was not possible. We placed a catheter in Bella's chest and started the periodic infusions. She made it through another school year before the treatment gradually became ineffective. By then, she lost the ability to walk independently, and became confined to a wheel- chair. The family was now ready to consider surgery. Then things got complicated.

The business of medicine trumped the art and science of healing. Bella's mother was a single parent who worked for a small business. The owner allowed her to take time off for Bella's health problems, but was not able to offer insurance to his employees. The experts in the complicated brain surgery were based at private institutions in other states. They were not required to accept Bella's state-sponsored insurance. One such institution had a contract with their state government's insurance. Could Bella go away for treatment?

The plan was simple: Bella's family would move, obtain state-sponsored insurance after establishing resident status, and plan for surgery. Bella's mother had some relatives in the state, and she was willing to relocate in a few months. We planned out a treatment and relocation plan over the next summer break, but it did not come to pass. Bella's mother was pregnant, and Bella became a big sister later that year.

During her middle school years, Bella spent more days at home and the hospital than at school. She was admitted several times after prolonged seizures, and each time, she took longer to recover. Meanwhile, Bella made many friends in the clinic and hospital. She had a never-ending supply of stories and surprises. Even during rough times, her eyes expressed the serenity that comes from the faith of a child. I shared her journey through the dark night, hoping for a better tomorrow. The dawn appeared to be at hand when a neurosurgeon joined the medical staff at my hospital.

The decision to undertake surgery was not an easy one. Was late always better than never? Bella had lost a significant amount of brain tissue after several years of relentless seizures. Younger children had better outcomes-Bella was a teenager. There was a high risk of complications, and a real possibility that seizures would persist after the surgery. There was also a possibility that Bella would succumb to the stress of the surgery. Conversely, without surgery, she faced an inevitable and irreversible loss of neurologic function. I supported Bella's mother's decision. We could remove the hurdles, but Bella would have to run her own race. 
The surgery was uneventful; the recovery was not. Bella's brain was slow to heal, and she had an extended convalescence period with several complications. During this time, she was minimally responsive, often only to pain and discomfort. Her brain waves were very slow and disorganized, but I did not see any evidence of seizure activity. I took her off some of the medications, hoping to clear a foggy brain.

On rounds, I stood by her bed, trying to elicit a response. I stroked her palm, and felt a feeble grasp. That was a reflex movement. "Now let go if you hear me." The grasp relaxed. I repeated the examination in the presence of the medical team, giving her ample time to respond. I'm not sure if they went along because I was the attending physician, but it was enough to start the process for transfer to a rehabilitation facility. Eight weeks later, Bella was lying in front of me with no reported progress.

Were all the years of effort in vain? If Bella had truly regressed to an unresponsive state, we had won the battle but lost the war. If, however, Bella was not getting a fair chance at rehabilitation, it was my responsibility to ensure that she received the best that medicine had to offer. She had gone through a lot, her seizures had stopped, and she was off sedating medications. I was not ready to write Bella off. I had to make a decision: either convince the staff or accept that I had lost my objectivity. Bella's future hung in the balance.

"Bella, tell me what you want." I raised the ante.

Instead of a grasp of the hand or movement of a limb, I had asked Bella for a much more complex task: process language, formulate a response, and use coherent words. In my head, I knew this was not expected until much later in the recovery process. In my heart, I wanted to engage the faith that I had seen in Bella's eyes. I repeated the phrase, and tracked time on my watch. Five seconds went by . . 10 . .
15. No response. Thirty seconds . . 40. Forty-five seconds later, Bella moved.

She arched her neck, pushed out her chin. Everyone waited with bated breath, eyes trained on Bella. Her breathing was the only sound in the silent room. When she opened her mouth, I leaned forward and stroked her forehead to let her know we were listening. And in the next moment, the wait was over.

"Go home," Bella said, in a loud and clear voice. Gasps, tears, and cheers greeted her.

I instructed the staff to expect slow responses to simple instructions. She needed plenty of social stimulation, and the time to build new brain connections. Patience and persistence would help her find the long road back home. The staff took the advice and the story back with them, and redoubled their efforts over the next few months. When Bella checked in for the next visit, she was once again the lively girl with a surprise.

"Did I surprise you, Dr. D?" She had a way of getting to the point.

"Yes, you did." I smiled in response.

"Know what?" she whispered, letting me in on a big secret.

"What, Bella?" I got into the game.

"I surprised myself," she laughed, as if we had concluded a game after 8 years.

Bella went home in due time. A few years later, she graduated from high school, and sent me this note:

Dr. D,

I am glad that you didn't forget me. I am doing well and I will be going to a technical school majoring in writing. And if you want to know how my mom is doing I am glad to say that she is doing good. We will keep you in our prayers. Remember to keep us in your heart and thoughts.

The faith of a child had delivered her from a devastating disease, by inspiring the rest of us to be patient through doubts and persistent beyond reason. 


\section{Neurology}

Reflections for December

O'Neill F. D'Cruz

Neurology 2011;77;2135-2136

DOI 10.1212/WNL.0b013e31823d761c

This information is current as of December 12, 2011

\section{Updated Information \&} Services

Subspecialty Collections

Permissions \& Licensing

Reprints including high resolution figures, can be found at: http://n.neurology.org/content/77/24/2135.full

This article, along with others on similar topics, appears in the following collection(s):

\section{All Pediatric}

http://n.neurology.org/cgi/collection/all_pediatric

Epilepsy surgery

http://n.neurology.org/cgi/collection/epilepsy_surgery_

\section{Plasticity}

http://n.neurology.org/cgi/collection/plasticity

Professional conduct and ethics

http://n.neurology.org/cgi/collection/professional_conduct_and_ethics Prognosis

http://n.neurology.org/cgi/collection/prognosis

Information about reproducing this article in parts (figures,tables) or in its entirety can be found online at:

http://www.neurology.org/about/about_the_journal\#permissions

Information about ordering reprints can be found online:

http://n.neurology.org/subscribers/advertise

Neurology ${ }^{\circledR}$ is the official journal of the American Academy of Neurology. Published continuously since 1951, it is now a weekly with 48 issues per year. Copyright Copyright $@ 2011$ by AAN Enterprises, Inc.. All rights reserved. Print ISSN: 0028-3878. Online ISSN: 1526-632X.

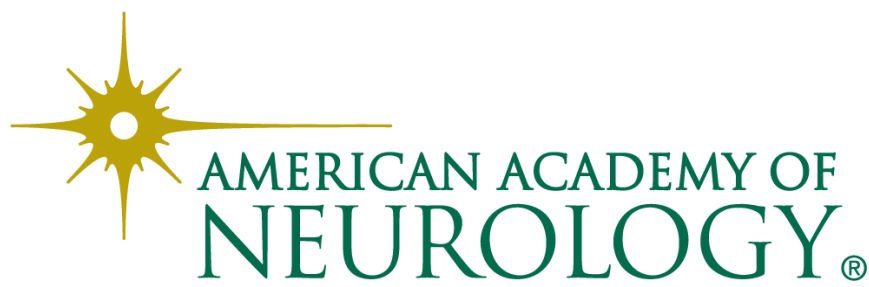

